\title{
Cluster formation processes in innovative development of Russian regions
}

\author{
Svetlana Soboleva \\ Volgograd State Medical University, \\ Chair of Economics and Management \\ Volgograd, Russia \\ svetlaso@mail.ru
}

\author{
Alexander Sobolev \\ Volgograd State Medical University, \\ Chair of Economics and Management \\ Volgograd, Russia \\ emvolgmed@mail.ru
}

\begin{abstract}
The paper is devoted to the study of regional processes of clustering and their attitude to innovative development of Russian regions. The factors that contribute to the effectiveness of these processes are examined. The study was conducted using the example of clusters of the pharmaceutical industry. The work carried out a comparative analysis of the regions of the Russian Federation - recipients of investments of the Federal budget within the Federal Target Program "Pharma $\mathbf{- 2 0 2 0 "}$ " in terms of formation and functioning of the cluster. It is revealed that active state investment support is not a determining factor in the success of regional clustering despite the achievement of federal goals. A more significant influence is provided by the institutional environment formed by the competent policy of local authorities to create favorable conditions for the functioning of business.
\end{abstract}

Keywords - cluster, innovative development, investments, institutional conditions, factors

\section{INTRODUCTION}

Macroeconomic indicators in Russia have recently shown fluctuations, which do not allow us to note that the economy has emerged from the crisis and is increasing its growth rates. In this regard, the issue of improving the efficiency of its performance remains topical. One of the possible ways is the formation of clusters that have a significant impact on regional competitiveness, reduce production costs, promote innovation activity and spread of knowledge.

The study of clustering processes involved foreign researchers (T. Andersson, M. Delgado, C. Ketels, J. Cortright, G. Lindquist, A. Markusen, A. Marshall, M. Porter, S. Rozenfeld, Ö. Sölvel, M. Enright etc.), and Russian scientists (L. Asaul, Yu. Vladimirov, A. Granberg, Y. Gromyko, O. Inshakov, E. Kutsenko, L. Markov, A. Migranyan, O. Lomovtseva, V. Tretyak, etc.).

The state policy to support clusters in the Russian Federation is among the priorities, which is reflected in a number of official documents of federal authorities implementing programs of investment support for clusters. However, in this regard, there are a number of questions: how do the investment programs of the state correlate with subsequent successes in regional development? What is the effectiveness of investment programs? Is state support a decisive factor in the emergence, development and successful functioning of clusters?
In this paper we try to answer these questions, aiming to identify the factors that affect both the efficiency of the clusters and the indicators of innovative development of the region. The research was carried out on the example of innovative and high-tech pharmaceutical industry. The state programs of its support have been implemented since 2009, which already allows us to sum up the interim results.

\section{MATERIALS AND METHODS (MODEL)}

The cluster phenomenon was described in the works of $\mathrm{M}$. Porter [1] dedicated to the competitiveness of regions. It was established that the effect of concentration of enterprises in a certain area contributes to improving the quality of products, spreading innovation, developing production, which ultimately affects the competitiveness of both cluster enterprises and the entire region. Clusters can be formed both naturally due to the prevailing regional conditions and artificially with state support. In Russia the active state policy of cluster formation has been applied to innovative industries.

The object of research in this work has been the clusters of the pharmaceutical industry. Their formation was given considerable attention and resources due to the need to strengthen country's pharmaceutical safety. In particular, from 2009 to 2011, a number of program documents were adopted $[2,3]$. Their analysis was useful for determining the conditions for the formation of pharmaceutical clusters. The paper also contains the analysis of investments in target regions and the study of indicators of the current state of clusters and regions that received support within state programs.

Both general scientific and specific economic methods of scientific knowledge are used in the paper, among them grouping, comparison, generalization, analytical and statistical methods, comparative analysis.

\section{RESULTS AND DISCUSSION}

Two basic documents on the development of the pharmaceutical industry - "The Strategy of Development of the Pharmaceutical Industry of the Russian Federation for the Period up to 2020" and The Federal Target Program "Development of the Pharmaceutical and Medical Industry of the Russian Federation for the Period till 2020 and the Further Prospect" defined the range of subjects of the Russian Federation having industrial enterprises and the potential for 
the development of the pharmaceutical industry and science. The Strategy created in 2009 named the regions in which the pharmaceutical industry is concentrated: Nizhny Novgorod, Kursk, Kurgan, Penza, Novosibirsk, Tomsk, Omsk, Altai, Moscow and St. Petersburg regions, the Republics of Bashkortostan and Tatarstan. The potential for development was also noted in Yaroslavl, Kaluga, Belgorod regions, Far Eastern and Southern Federal Districts [2].

The Federal Target Program (FTP "PHARMA 2020", 2011) specified the tasks and defined a number of subjects recipients of investments. Thus, in general, one or more projects in some regions received federal budget funds (million rubles, m. RUR): Moscow (with the region) - 9620 (11 projects), Yekaterinburg - 1597 (2 projects), Nizhny Novgorod - 1130 (1 project), St. Petersburg-1034 (3 projects), Volgograd - 990 (1 project), Yaroslavl - 677 (1 project), Kazan 629 (1 project) (Table 1) [3].

The two program documents, the Strategy and the FTP, do not fully correlate with each other in terms of identifying priority actors for investment. Thus, not all the regions mentioned in the Strategy received state support, for example, Altai, Kaluga, Novosibirsk, Tomsk. At the same time, among those who got it there are territories not mentioned in the first document. A significant proportion of the investment of the federal budget $(61.3 \%)$ within the Federal Target Program "PHARMA 2020" was given to 11 projects in Moscow and Moscow region. The remaining $(38.7 \%)$ were distributed among six subjects of the Russian Federation for 8 projects. This demonstrates the lack of correlation between this document and the purposeful policy on smoothing territorial imbalances and misalignment in the distribution of Federal funds in favor of the capital, which does not help to equalize the spatial development of the country. At the same time, it should be noted that Moscow and the Moscow region were the only entity participant of the FTP, where there was an innovative cluster at the time of investment, there were no other clusters in the regions, and this program was supposed to contribute to their formation.

The most capital-intensive project was "State Plant of Medical Drugs" in Moscow with $2184 \mathrm{~m}$. RUR. Other projects received limited investments. Research Institute of Technical Physics and Automation in Moscow got $70 \mathrm{~m}$. RUR to create a center for the production, assembly and engineering support of units for diagnostic medical equipment. The average investment of the Federal budget for one project amounted to $825.1 \mathrm{~m}$. RUR, and the average value in the region amounted to $2239.57 \mathrm{~m}$. RUR. Moscow with the region received 4.29 times more funds, and Kazan 3.56 times less than the average value of investments by region.

As follows from the documents of the Ministry of Industry and Trade, in general the program has shown its effectiveness [4]. Within the project, 25 industrial enterprises have been built in Russia since 2009, 30 production sites have been modernized, 28 medicines have been put on the market.
TABLE I. SUBJECTS OF THE RUSSIAN FEDERATION WITH POTENTIAL FOR THE DEVELOPMENT OF THE PHARMACEUTICAL INDUSTRY

\begin{tabular}{|c|c|c|c|c|}
\hline Region & $\begin{array}{l}\text { Concentrat } \\
\text { ion of } \\
\text { pharmaceu } \\
\text { tical } \\
\text { industry / } \\
\text { potential } \\
\text { (according } \\
\text { to the } \\
\text { Strategy) }\end{array}$ & $\begin{array}{c}\text { Participation } \\
\text { in PHARMA } \\
\text { 2020, m. RUR / } \\
\text { number of } \\
\text { projects }\end{array}$ & $\begin{array}{c}\text { Best } \\
\text { project } \\
\text { s of } \\
\text { innova } \\
\text { tive } \\
\text { cluster } \\
\text { s }\end{array}$ & $\begin{array}{l}\text { Regional } \\
\text { rank of } \\
\text { innovative } \\
\text { developme } \\
\text { nt }\end{array}$ \\
\hline Altai & $+/+$ & - & & 27 \\
\hline Volgograd & & $+990 / 1$ & & 39 \\
\hline $\begin{array}{l}\text { Yekaterinb } \\
\text { urg }\end{array}$ & & $+1597 / 2)$ & & 17 \\
\hline Kazan & $+/-$ & $+629 / 1$ & & 1 \\
\hline Kaluga & $-1+$ & - & + & 6 \\
\hline $\begin{array}{l}\text { Moscow } \\
\text { (with } \\
\text { region) }\end{array}$ & $-/+$ & $+9620 / 11$ & + & 2 \\
\hline $\begin{array}{l}\text { Nizhny } \\
\text { Novgorod }\end{array}$ & $+/+$ & $+1130 / 1$ & & 4 \\
\hline $\begin{array}{l}\text { Novosibirs } \\
\mathrm{k}\end{array}$ & $+/-$ & - & + & 11 \\
\hline $\begin{array}{l}\text { St. } \\
\text { Petersburg }\end{array}$ & $-/+$ & $+1034 / 3$ & & 3 \\
\hline Tomsk & $+/-$ & - & + & 9 \\
\hline Yaroslavl & $-/+$ & $+677 / 1$ & & 28 \\
\hline
\end{tabular}

In 2014, the share of domestic drugs on the List of Vital Essential and Necessary drugs (VEN), which is a key indicator of the FTP, was the target of $67 \%$. However, the answer to the question of how the implementation of the Program relates to the development of Russian territories has not yet been found.

In 2017, the study of the Higher School of Economics "Cluster Policy: Achieving Global Competitiveness" [5] summed up the results of the competition of innovative clusters, participants of the priority project of the Ministry of Economic Development, which also reflected the state of affairs in the pharmaceutical industry. The list of the best participants included four pharmaceutical clusters: Kaluga, Moscow and Moscow region, Novosibirsk and Tomsk, of which only the capital region was the recipient of funds under the Federal Target Program. Consequently, the formation of clusters in other advanced regions did not depend on federal investments, but relied on the support of local authorities.

At the same time, the same subjects are at a high place in the "Rating of Innovative Development of the Russian Federation in 2017" [6]. It determines the Innovative Development Index, taking into account the factors of socio-economic conditions of innovations, scientific and technical potential, the actual innovation activity and the quality of innovation policy. Thus, in contrast to the usual statistical indicators, which are essentially retarded, it acts as a leading indicator reflecting the vector of the future state of the region. In our opinion, this index is especially relevant in the analysis of the state of innovative industries, including pharmacy. In 2017 Moscow ranked the 2nd place, Kaluga - the 6th, Novosibirsk - the 11 th, Tomsk -the 9th. 
All leading regions actively contribute to the formation of clusters in their territories. They have established bodies of administrative support and provision of specialized services to its participants. Their regional policy to support the formation of clusters is of particular interest as a model for further replication of best practices. Thus, in Kaluga a specialized organization JSC "Agency for Innovative Development Center of Cluster Development of Kaluga Region" was created. It provides various types of service for cluster enterprises, promotes access to sources of financing, helps developing cooperation and communications of cluster members, etc. As it was noted during The Gaidar Forum in 2018 , the key to the success of innovative clusters is the entry of their enterprises into the international market [7]. It is also important to have developed soft - skills - knowledge of a foreign language and communications [7, 8]. Kaluga cluster consists of 63 organizations, including medium and large foreign pharmaceutical companies - Novo Nordisk, AstraZeneka, Berlin-Pharma, etc. Not relying on the federal resource Kaluga managed to attract private foreign and Russian investors, localize anchor companies, which unfortunately did not happen in all regions. Thus Sharma Pharmaceuticals Pvt. Ltd. planned to build a plant in Volgograd which was not implemented in the end.

Kaluga managed to create comfortable business environment by concentrating government support measures and by building cooperative chains. Of course, we cannot ignore beneficial geographical location and proximity to the capital region, but not all the regions of the Central Federal District have achieved such impressive successes as Kaluga. The region has wide transport and special infrastructure, an international airport and two universities, 12 industrial parks and a special economic zone. In 2017 the volume of produced medicines has reached 28 billion rubles. During the work of the cluster 9.5 thousand jobs were created [7].

\section{CONCLUSION}

In conclusion, it should be noted that there was no direct link between the volume of public investment within the Federal Target Program and the level of development of the cluster. Moreover, state support from the federal budget is not the key to the success of the cluster. Thus, the only region that received investments from the Federal Target Program and developed the innovative cluster is Moscow. At the same time, the success of cluster formation in the region positively correlates with the level of its innovative development. The regions with functioning clusters occupy the first lines of the
Rating. Given that the Index of innovative development can act as a leading indicator, we propose to use it for early diagnostics of innovative changes in the territorial entities.

The main factors contributing to the success of the cluster and innovative development of the region, in our opinion, are the institutional conditions provided by the relevant policy of local authorities - the formation of regional development institutions that promote the implementation of innovative projects of resident enterprises; reducing bureaucratic barriers; the establishment of fair tariffs for services of natural monopolies; the provision of tax benefits, etc.

It should be noted that the analysis made is the first step towards a deeper study of the impact of institutional factors on the formation of regional clusters, as well as on improving the functioning of the regional economy.

\section{References}

[1] M. Porter, On competition [Konkurencija], Moscow: Wiliams, 2005

[2] Strategy of development of Russian pharmaceutical industry for the period up to 2020. [Strategija razvitija farmacevticheskoj promyshlennosti Rossijskoj Federacii na period do 2020 goda] National pharmaceutical portal. http://www.pharmmedexpert.ru/pharma2020.php

[3] The Federal target program "Development of the pharmaceutical and medical industry of the Russian Federation for the period till 2020 and the further prospect" [Federal'naja celevaja programma «Razvitie farmacevticheskoj i medicinskoj promyshlennosti Rossijskoj Federacii na period do 2020 i dal'nejshuju perspektivu]. http://www.fcpfarma.ru/

[4] The Ministry of industry and trade of Russian Federation official website. http://minpromtorg.gov.ru

[5] V. L. Abashkin, S. V. Artemov, E. A. Islankina, others, Cluster policy: achieving global competitiveness [Klasternaja politika: dostizhenie global'noj konkurentosposobnosti], Moscow: Ministry of economic development of Russia, JSC RVC, National Research University "Higher school of Economics", 2017.

[6] Abdrakhmanova G. I., P. D. Bakhtin, L. M. Gokhberg and others, Rating of innovative development of the Russian Federation regions [Rejting innovacionnogo razvitija sub\#ektov Rossijskoj Federacii], Issue 5, Moscow: National Research University "Higher school of Economics", 2017.

[7] Russian cluster Observatory [Rossijskaja klasternaja observatorija]. http://cluster.hse.ru

[8] Bortnik I. M., Zemtsov S. P., Ivanova O. V., Kutsenko E. S., Pavlov P. N., Sorokina A. V., The Formation of innovative clusters in Russia: results of the first years of support [Stanovlenie innovacionnyh klasterov $\mathrm{v}$ Rossii: itogi pervyh let podderzhki]. http://institutiones.com/innovations/2681-stanovlenie-innovacionnyxklasterov-rossii.html 